2015, volume 4, issue 2

Ciechan-Kujawa M. (2015). Professional financial and accounting services in the light of European Union directives and the deregulation of professions in Poland - current status and research needs. Copernican Journal of Finance \& Accounting, 4(2), 65-77. http://dx.doi.org/10.12775/ CJFA.2015.016

\author{
Marlena Ciechan-Kujawa* \\ Nicolaus Copernicus University
}

\title{
PROFESSIONAL FINANCIAL AND ACCOUNTING SERVICES \\ IN THE LIGHT OF EUROPEAN UNION DIRECTIVES \\ AND THE DEREGULATION OF PROFESSIONS IN POLAND - CURRENT STATUS AND RESEARCH NEEDS
}

Keywords: financial and accounting services, deregulation, Directive of the European Union, security of business transactions, sustainable development, corporate social responsibility.

\section{J E L Classification: M40, M41, M42, M48.}

Abstract: The article describes the issue of the impact of legislative changes on the market of professional accounting and financial services. It discusses the scope and essence of the changes both to the directives of the European Union and the deregulation of the profession of the accounting and finance in Poland. This article contains findings regarding the experience of European countries and presents the selected research results. In conclusion, the author indicates and justifies direction in research, which is essential to identify the determinants of the functioning and development of professional finance and accounting services in Polish economic practice after the legislative changes as well as the mechanisms of their impact on the risks (opportunities and threats) for sustainable development of entities and security of business trading.

Translated by Marlena Ciechan-Kujawa

Date of submission: January 12, 2015; date of acceptance: February 15, 2015.

* Contact information: marlenac@econ.umk.pl, Nicolaus Copernicus University, Gagarina 13A, 87-100 Toruń, Poland, phone: +48 607772670. 


\section{INTRODUCTION}

Financial and accounting services (including accounting, bookkeeping, auditing) are recognized in Poland and Europe as business services in the broad sense and as such constitute a set of services provided by qualified personnel who have gained their competence owing to the mastering of a significant scientific discipline. Financial and accounting services include the organization of accounting, bookkeeping and tax accounting, preparation of financial statements (and other) for internal and external purposes, financial auditing and other services in the field of finance and accounting, and impact the quality of the whole process of accounting (Wiśniewska 2013), and thus the management process in the entity. A wide range of their functions (confirming, instrumental, verifying, informational, streamlining, advisory, educational) goes beyond the sphere of the entity's activity and affects both internal and external stakeholders' decision-making process (Ciechan-Kujawa 2014a).

The new situation on the market of professional financial and accounting services created by the legislative changes may create significant opportunities and risks for the importance and development of these services. The openness of these professions caused by the deregulation raises a question about the impact of these changes on the quality of services. In addition, there are hypothesis that the changes will boost the availability and price competitiveness of these services, which may be an opportunity, especially for small businesses, to make a use of them on a larger scale in building the competitive potential. Also the EU directives introduced seem to be essential for the changes in the market demand for financial and accounting services. This applies to both quantitative and qualitative changes.

\section{RESEARCH METHODOLOGY}

The purpose of the article is an overview of the research carried out in European countries regarding the impact of legislative changes on the market of financial and accounting services, as well as justification of needs and an indication of the direction of the studies necessary to carry on the Polish market. Present situation leads to asking questions about the meaning and potential of professional finance and accounting services, as well as about the possibilities and directions of their development in the light of the changing legislation and of the 
impact of these changes on the activity of economic entities, and their stakeholders understood in the broad sense.

\section{THE ESSENCE OF THE MARKET CHANGES IN THE ACCOUNTING AND FINANCIAL SERVICES RESULTING FROM EU DIRECTIVES}

It should be noted, that legislative changes being currently implemented in Poland and Europe, are far-reaching in their scope. From the point of view of changes in the directives, an important role in the development of the financial and accounting services market should be attributed to the requirements resulting from the following European Union directives: 2006/43/EC on statutory audits of annual accounts and consolidated financial statements, 2013/34/ EC on the annual financial statements, consolidated financial statements and related reports of certain types of undertakings, 2013/56/EC on statutory audits of annual accounts and consolidated financial statements.

Directive 43 has introduced a new quality of financial auditing and of the audit profession in Europe. Due to the globalization of the economy and the resulting growing risk of global crises and due to the role statutory auditors play in ensuring the security of business trading, this directive is constantly evolving. In recent years, the most important changes in this directive have resulted from the passing of the Directives 2013/34/EC and 2014/56/EC of the European Parliament and of the Council. Directive 34 came into effect on 20 July 2013 and imposed on EU Member States the obligation to adjust their national laws to its regulations no later than by 20 July 2015. Its provisions introduce simplifications regarding the SMEs sector, which will contribute to reducing administrative burden and costs of micro and small businesses (in accordance with the programme of the European Commission 'Smart Regulations in the European Union' and the strategy 'Europe 2020'). At the same time they affect the decline in demand for statutory audit of financial statements. According to some researchers (Maciejewska 2014; M. Ślebzak, K. Ślebzak 2014, 2-6), over a longer period of time these changes may constitute a threat to the security of business trading and at the same time exert a negative influence by reducing the quality of financial reports and tax collection. Moreover, the changes resulting from the directive have an impact on the reporting delivered by entities: they define the minimum disclosure requirements for small entities, the manner and extent of disclosures made under the notes and the report of activities, expand the scope of the report on the activities of public interest entities by the statement 
of the conformance with the principles of corporate governance, as well as introduce a reporting obligation for large units and public interest entities concerning payments to governments (the country-by-country reporting system).

On 27 May 2014 a legislative packet concerning financial audit was issued in the Official Journal of the European Union. It contains Directive 56 and Regulation 537. The provisions of the directive are intended also to strengthen the independence of statutory auditors and audit firms, to improve the quality of audits conducted within the European Union, to strengthen the public oversight of the audit profession and activities of audit firms, to tighten the regulations for statutory auditors and audit firms examining public interest entities. The provisions of the directive 56 must be implemented into the national law of the member states. The deadline to implement the provisions of the directive and the regulation is two years from their date of entry into force, i.e., until 16 June 2016.

\section{THE APPROACH TO DEREGULATION}

\section{OF THE ACCOUNTING AND FINANCIAL PROFESSIONS}

Nevertheless, the changes in the regulations on access to professions are also important for the development of the finance and accounting services market. The general approach to the regulations in the scope of accounting differs depending on the country, reflecting the importance of strong traditions and different historical evolution of these professions. Some countries of the European Union, such as, for instance, the Czech Republic, Malta, Norway, Belgium, Greece, Hungary, Italy, Austria, Luxembourg, France, and Romania, have regulations. The differences in regulatory approaches generally result from a clear distinction between audit services and accounting services as well as from different perceptions of independence, quality and verification (Commission 2013 , 18). Some EU member states do not see the need for independence, indicating that financial and accounting services are generally outsourced, and the service provider is in any case obliged to comply with the accounting standards. However, some opinions appear on the need for analysing services that are provided by unqualified accountants, and these services may be associated with the possible responsibility of the business to third parties and the need for their regulation to protect the public interest. These services include all services that cover the entity-service provider-report reader relationship. Some member states are of the opinion that in order to assure the quality of financial and accounting services, voluntary or compulsory qualifications of persons 
providing such services are necessary (for example, in Malta), as well as restrictions concerning the legal form and/or shares possessed (for instance, in Belgium, Austria, Italy, France, the Netherlands, or in the Czech Republic).

In Poland, the Act on facilitating access to perform certain regulated professions came into force on 10 August 2014. The so-called second tranche deregulates nine professions of the financial market. In the scope of financial and accounting services the changes concern in particular the following:

- In the scope of bookkeeping services the requirement of the possession of related higher education or completed postgraduate studies in accounting was abandoned. Also, the requirement of the state examination was abandoned and was replaced by the market self-regulation of bookkeeping services.

- In the case of statutory auditors, access to the profession is facilitated, among other things, by recognising the theoretical basis of related and completed higher education covering in its scope the knowledge required in the qualification procedure, the reduction of the mandatory re-training of auditors.

- Deregulation in the tax consultant profession aims to reduce the scope of tax advisory services at present reserved only for certain groups of subjects. Some services rendered to taxpayers, such as, for instance, providing advice, opinions and explanations in the scope of taxes, customs duties, administrative enforcement matters relating to these duties, keeping booking, tax and other records, preparing tax returns and providing assistance in this regard will be almost completely deregulated.

\section{THE IMPACT OF THE LEGISLATIVE CHANGES ON THE ACCOUNTING AND FINANCIAL SERVICES MARKET IN THE EUROPEAN COUNTRIES - RESEARCH RESULTS}

The partial legislative changes in the scope of providing certain financial services have already been introduced in some European countries, for example, in 1994 they were introduced in the United Kingdom, in 2006 in Denmark, in 2007 in Finland. In 2008 they were introduced in Sweden and Malta. However, the consequences of these changes in regulations have not been researched comprehensively. The most extensive study was conducted in Sweden. What was reported in other countries were unmet expectations of the effects of deregulations in the range of increased customer orientation, innovation in ser- 
vices (Kinney 2005; Seow 2001; SOU 2008, 32), or only selected aspects were considered such as, for example: implications for rates and scope of services (McMeeking et al., 2007), the concentration of the auditing market (Basioudis, Ellwood 2005) internal work processes and systems for the management and control of audit firms (Pierce, Sweeney 2004). Researchers explain the lack of significant observed changes in the strategy of service providers by high demand for accounting services currently delivered (Tabone, Baldacchino 2003; Chung, Narasimhan 2001) and by oligopolistic behaviours of audit firms, such as collusions or imitations (Moizer, Turley 1989). The studies conducted in Sweden showed rather moderate changes resulting from deregulation, however, the following were observed: a slight trend toward greater cooperation with customers, no significant changes in the structure and processes of entities, no openness to the introduction of new services, minor changes in the approach to promotion of services and an increase (and not the expected decrease) in prices. The researchers emphasize the occurrence of certain inertia in response to the market deregulation (the studies were carried out immediately after the deregulation of 2009) and they indicate that the changes were rather conservative adjustments rather than a radical transformation of the finance and accounting services market in Sweden (Ahlberg et al., 2011).

The impact of regulation on access to professions on the key indicators such as quality of service, remuneration of professionals, prices for consumers and the overall impact on employment has already been researched in some countries, but in relation to a wide range of business services. In several of these studies (Kugler, Sauer 2005) it was concluded that it is impossible to demonstrate the correlation between regulation of access to professions and the quality of service. The outcome of other studies (Kleiner, Krueger 2013) indicate that the average salary of professionals performing regulated professions is much higher than in non-regulated professions, and that the introduction of regulated access to a profession increases earnings of its representatives. Therefore, there exists a risk that such an increase in earnings will translate into prices to the detriment of people using such services. As follows from surveys conducted in Germany (Plantl et al., 2009), regulating professions may adversely affect the mobility of professionals, since it does not allow them to respond quickly to emerging opportunities in the labour market. It is also emphasised that capital requirements existing in some countries limit the creation of multidisciplinary professional firms as well as the choice of financing and business models for 
companies, and thus may hinder innovation in services, have a negative impact on prices of services and competitiveness of these services.

\section{JUSTIFICATION THE NEED FOR RESEARCH ON THE POLISH MARKET}

In the context of such broad legal changes the author assumes a significant impact of the above on both the competitive potential of entities and on the quality, competitive pricing and innovative services. Similar to the studies conducted in Sweden, is important to recognize the methods of absorbing legislative changes, also - an issue that has not been researched yet - the internal and external conditions of absorption as well as their impact on the quality, price competitiveness and innovation services. This last issue was the subject of research in the United Kingdom, as part of broader research on innovative professional business services. The analyses conducted showed that among the barriers to innovation in professional financial and accounting services, a key role is ascribed to the regulation of the activity and besides to strong functional specialization, the negative balance of costs and benefits and also to the organizational culture of companies providing financial and accounting services based on a high tendency to risk avoidance (The role of Innovation 2013). In this sector it is indicated that regardless of the size of the entity both aspects: the value for money and efficiency in adapting to changing individual needs of enterprises and the guaranty of delivering expert services best in its class and based on the knowledge of the market on which the entity operates are equally important. The outcome of the research leads to a conclusion that there is a mismatch between customer perception and the reality of innovation of services in this sector. Therefore, what needs to be explained is the matter of the concept and perception of innovation in this sector.

The specificity of financial and accounting services seems to require also (especially in the context of the legislative changes introduced) a wider analysis of the concept and quality attributes, as well as of the costs and effects of assuring quality and of a failure to assure quality. For decades competence and independence (ethics) (DeAngelo 1981) have been indicated as the key attributes of the quality of professional financial and accounting services. However, until now researchers have not answered the question of whether the quality of professional financial and accounting services ought to be measured by means of the level of quality in the strict sense (proper performance of the service - that means consistent with the contract and/or the applicable standards 
set out clearly in the regulations, standards, and codes), or - as it is in the case for other professional services (Rogoziński 2012, 379) - in the broad sense that includes in the definition of quality such elements as the perspective of the service provider and the perspective of the service recipient, as well as the dependence in the dyadic relation between the service provider and its recipient and the market network connections. Therefore, when assessing the quality of financial and accounting services in a broader sense, the concept of a syncretic quality can be considered (taking into account both the expectations of the client and the professionalism of the service provider) which represents the result of the quality of the evidence, the quality of perception, and the quality of relationships. The systematization of this knowledge is so significant that - as indicated by the researchers - the quality of financial and accounting services provided is essential for their value (Watts, Zimmerman 1981), and, as indicated by some authors, it is value that shapes demand for them.

The role of modern financial-accounting services should be providing useful information to the entity and its various stakeholders to be applied when making economic, social and environmental decisions, and when checking whether the entity fulfils its responsibility for the sustainable development of the organization (Gray 2011,11). The relation of the quality of financial and accounting services and perception of their value by customers and other stakeholders is important from the point of view of the legislative changes but is insufficiently recognized by empirical studies. The relation requires, in particular, the analysis of the conditions and mechanisms that shape it. It should be the subject of the research both in the context of the impact of quality on the indicators of the development of the entity and the security of business trading.

The debate on the regulation of the accounting profession highlights the following issues of public interest: the need to protect the consumer, the independence of the profession, the quality of services, the avoidance of tax evasion and money laundering, as well as professional secrecy. Therefore, it seems reasonable to consider within research such issues as removing or reducing the requirements for access to financial and accounting professions in Poland (based on European solutions) may affect the economic and social costs/benefits identified at the level of economic entities, their stakeholders and the economy. The non-uniform approaches to the range of the regulation of financial and accounting services can affect different levels of cost/socio-economic benefits, which, as indicated in Commission staff working document (2013) has not been examined so far. The Polish government assumes that the solutions 
to heighten access to regulated professions will increase competition, resulting in a reduction in prices, higher quality and greater availability of services. As well as the changes will have a positive affect on increasing the amount of new jobs. Moreover, deregulation will reduce the burden of running a business. The government justifies, that current regulations of the accounting profession were an insufficient motivator for companies to identify customer needs and adapt its offer to their needs and develop new products and services (Komentarz 2014). Therefore, the assessment of the Polish solutions in the scope of deregulation (with regard to applicable direct, indirect regulation and self-regulation), as well as the impact of introduced deregulations on the opportunities and threats to the sustainable development of economic entities and on the security of business trading can be really innovative. Some of the aspects were to a greater or lesser extent researched separately in Poland. They covered either selected aspects or selected services in the field of accounting and concerned (Świderska et al., 2010; Dobija 2014; Boguszewski 2012). Based on the analysis of previous studies the following research hypotheses can be assumed:

1. The deregulation of financial professions and the new EU directives impact the level of the quality, innovation, price competitiveness of financial and accounting policies, and changes in the strategy of their providers on the Polish market.

2. The level of the quality, innovation and price competitiveness of professional financial and accounting services impact the trends in shaping the security of the indicators of business trading.

3. The level of the quality, innovation and price competitiveness of professional financial and accounting services impact the trends in shaping the indicators of sustainable enterprise development.

4. Assurance of or a failure to assure the quality of professional financial and accounting services creates opportunities and risks for entities and their stakeholders impacting the perceived value of services and thereby increasing gains (benefits) and socio-economic losses (costs).

\section{CONCLUSIONS}

The quality of financial and accounting services can have considerable economic and social consequences resulting from wrong decisions taken on the basis of unreliable, incomplete, untrue and inadequate data supplied to internal or external stakeholders. Both accounting and the process of financial data prep- 
aration are becoming more complex. Introducing innovative business models creates demand for the development of information systems for financial and management accounting supporting the evaluation of their effectiveness. Data preparation processes are becoming more complex, and their interpretation more complicated. The demand for some services also stems from the asymmetry in the access to information of various stakeholder groups. This is particularly important in relation to issues which may impact the entity's the ability to unthreatened functioning and its development potential which may include, for instance, the compliance of the entity with legal regulations and generally accepted standards, the level of the consideration of the needs and expectations of various stakeholders and the effectiveness of their satisfaction, the effectiveness of the allocated resources and the effectiveness of the action undertaken (Ciechan-Kujawa 2014b). The question about facilitated access to the profession resulting from the deregulation and its impact on the competence of service providers remains vital. Thus, the context of the current extensive legislative changes as well as a systemic recognition of the importance of professional financial and accounting services for businesses, stakeholders' decisions and socio-economic effects of these relations requires comprehensive studies. The research should concern the determination of the impact of legislative changes in the area of deregulation of financial and accounting professions and the new European Union (EU) directives on the development of the professional finance and accounting services market, as well as the consequences of these changes for a broad range of recipients, in particular economic entities and their stakeholders. The main directions can be defined as follows:

1. Identifying opportunities and threats arising from the legislative changes (in particular, the deregulation of professions and the new EU directives) and explaining the mechanisms of the impact of these changes on the competitive potential of financial and accounting services as well as the conditions and methods of its absorption.

2. Determining the strength, scope and nature of the impact of the effects of the legislative changes in professional financial and accounting services on the operation and sustainability of modern enterprises and the security of business trading.

3. Identifying the conditions, explaining the formation of mechanisms and defining the category of socio-economic effects resulting from assuring or a failure to assure quality of professional financial and accounting services. 


\section{REFERENCES}

Ahlberg, J., Yrjö Collin, S., \& Lazarevska, A. (2011). Audit firm adaption to expected deregulation of statutory auditing: The Swedish Experience, The Corporate Governance Research Group At Linnæus University, Working Papers Series In Corporate Governance 2011:1.

Basioudis, I.G., \& Ellwood, S. (2005). An empirical investigation of price competition and industry specialisation in NHS audit services. Financial Accountability and Management, 21 (2), 219-247. http://dx.doi.org/10.1111/j.1468-0408.2005.00216.x.

Boguszewski, B. (2012). Komunikat z badań opinii o deregulacji zawodów w Polsce, Fundacja Centrum Badania Opinii Społecznej, Warsaw, BS/92/2012, http://www. cbos.pl/SPISKOM.POL/2012/K_092_12.PDF (accessed: 12.09.2014).

DeAngelo, L.E. (1981). Auditor size and audit quality. Journal of Accounting and Economics, 3(4), 183-199. http://dx.doi.org/10.1016/0165-4101(81)90002-1.

Chung, S., \& Narasimhan, R. (2001). Perceived value of mandatory audits of small companies. Managerial Auditing Journal, 16(3), 120-123. http://dx.doi.org/10.1108 /02686900110385551.

Ciechan-Kujawa, M. (2014a). Wielowymiarowy audyt biznesowy. Wartość dodana dla organizacji i interesariuszy, Wydawnictwo Naukowe UMK, Toruń.

Ciechan-Kujawa, M. (2014b). Atrybuty innowacyjnych usług audytorskich oraz determinanty ich wdrażania w świetle wyników badań, [in:] Współczesne problemy rachunkowości w teorii i praktyce, Wydawnictwo Uniwersytetu WarmińskoMazurskiego w Olsztynie, Olsztyn, 63-72.

Commission staff working document on the outcome of the peer review on legal form, shareholding and tariff requirements under the Services Directive (2013), COM (2013)/676, Brussels, 2.10.2013, SWD 402 final.

Directive 2006/43/EC of the European Parliament and of the Council of 17 May 2006 on statutory audit of annual accounts and consolidated accounts (OJ L 157, 9.6.2006).

Directive 2013/34/EU of the European Parliament and of the Council of 26 June 2013 on the annual financial statements, consolidated financial statements and related reports of certain types of undertakings, (OJ L 182, 29.6.2013).

Directive 2014/56/EU of the European Parliament and of the Council of 16 April 2014 amending Directive 2006/43/EC on statutory audits of annual accounts and consolidated accounts (OJ L 158, 27.5.2014).

Dobija, D. (2014). Audyt finansowy we współczesnych systemach społecznych. Funkcje i praktyka, Wolters Kluwer S.A., Warsaw.

Gray, R. (2011). Thirty years of Social Accounting, Reporting and Auditing: What (If Anything) Have We Learnt? Business Ethics: A European Review, 10 (1), 9-15. http:// dx.doi.org/10.1111/1467-8608.00207.

Kinney (Jr), W.R. (2005). Twenty-five years of audit deregulation and re-regulation: What does it mean for 2005 and beyond? Auditing: A Journal of Practice \& Theory, 24, Supplement, 89-109. http://dx.doi.org/10.2308/aud.2005.24. 
Kleiner, M.M., \& Krueger, A.B. (2013). Analyzing the Extent and Influence of Occupational Licensing on the Labor Market. Journal of Labor Economics, 31, S1, 173 - 202. http://dx.doi.org/10.1086/669060.

Komentarz do projektu ustawy o zmianie ustaw regulujących warunki dostępu do wykonywania niektórych zawodów, przedłożony przez ministra sprawiedliwości, https://www.premier.gov.pl/wydarzenia/decyzje-rzadu/projekt-ustawy-o-zmianieustaw-regulujacych-warunki-dostepu-do-wykonywania.html (accessed: 12.08. 2014).

Kugler, A.D., \& Sauer, R.M. (2005). Doctors without Borders? Relicensing Requirements and Negative Selection in the Market for Physicians. Journal of Labor Economics, 23 (3), 437-465. http://dx.doi.org/10.1086/430283.

Maciejewska, I. (2014). Implementacja dyrektywy 34 - szansa czy zagrożenie dla przyszłości zawodu biegłego rewidenta w Polsce?, http://abc.online.wolterskluwer. plWKPLOnline (accessed: 12.09.2014).

McMeeking, K.P., Peasnell, K.V., \& Pope, P.F. (2007). The effect of large audit firm mergers on audit pricing in the UK. Accounting and Business Research, 37 (4), 301-319. http://dx.doi.org/10.1080/00014788.2007.9663314.

Moizer, P., \& Turley, S. (1989). Changes in the UK market for audit services: 1972-1982. Journal of Business Finance \& Accounting, 16(1), 41-53. DOI: 10.1111/j.14685957.1989.tb00003.x.

Pierce, B., \& Sweeney, B. (2004). Cost-Quality conflict in audit firms: An empirical investigation. European Accounting Review, 13(3), 415-441. DOI: 10.1080/09638 18042000216794.

Rogoziński, K. (2012). Zarządzanie wartością z klientem, Wolters Kluwer Polska Sp. z o.o, Warsaw.

Seow, J-L. (2001). The demand for the UKsmall company audit-An agency perspective.International Small Business Journal, 19(2), 61-79. DOI: 10.1177/0266242601192004.

SOU 2008:32 (2008), Avskaffande av revisionsplikten för små företag. Abolition of the statutory audit for small firms, Stockholm, Justitiedepartementet.

Ślebzak, M., \& Ślebzak, K. (2014). Spodziewane zmiany ustawy o rachunkowości a obligatoryjne badania sprawozdań finansowych. Rachunkowość, 8, 2-6.

Świderska, G. K., Gruszczyński, M., Borowski, S., Karioen, M., Karwowski, M., \& Pielaszek, M. (2010). Wpływ zakresu ujawnionych informacji na poprawę ochrony inwestorów oraz pozycję konkurencyjną emitentów papierów wartościowych, [in:] Studia i Prace Uniwersytetu Ekonomicznego w Krakowie, 14(2), 260-269.

Ustawa z 29 maja 2014 r. o ułatwieniu dostępu do wykonywania niektórych zawodów regulowanych, Dz. U. 2014, poz. 768.

The role of Innovation in the Professional Services Industry (2013), FTI Consulting, www.fticonsulting.com/global2/media/collateral/united-states/innovation-index.pdf (accessed: 07.09.2014).

Tabone, N., \& Baldacchino, P. J. (2003). The statutory audit in owner-managed companies in Malta. Managerial Audit Journal, 18(5), 387-398. http://dx.doi. org/10.1108/02686900310476855. 
Professional FinANCIAL AND ACCOUNTING SERVICES...

Watts, R.L., \& Zimmerman, J. L. (1981), The Markets for Independence and Independent Auditors, Working paper, University of Rochester.

Wiśniewska, J. (2013). Klasyfikacja usług wykonywanych przez biegłych rewidentów. Copernican Journal Finance \& Accounting, 2(2), 203-214. http://dx.doi. org/10.12775/CJFA.2013.024. 
